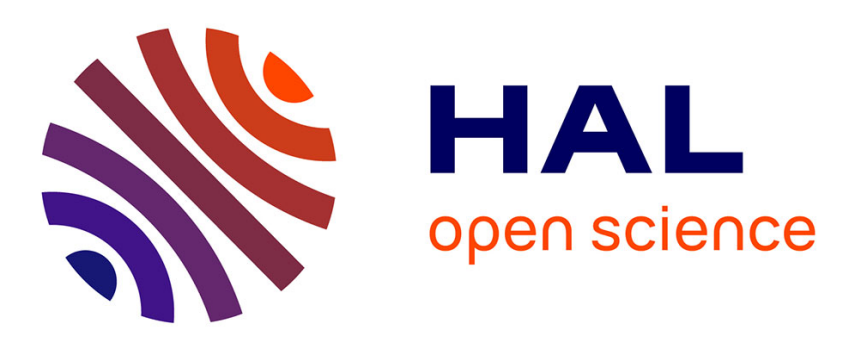

\title{
Interlibrary loan and document supply in France - the Montpellier meeting
}

Joachim Schöpfel

\section{To cite this version:}

Joachim Schöpfel. Interlibrary loan and document supply in France -the Montpellier meeting. Interlending and Document Supply, 2005, 33 (1), 4 p. 10.1108/02641610510582180 . sic_00001428

\section{HAL Id: sic_00001428 \\ https://archivesic.ccsd.cnrs.fr/sic_00001428}

Submitted on 26 Apr 2005

HAL is a multi-disciplinary open access archive for the deposit and dissemination of scientific research documents, whether they are published or not. The documents may come from teaching and research institutions in France or abroad, or from public or private research centers.
L'archive ouverte pluridisciplinaire HAL, est destinée au dépôt et à la diffusion de documents scientifiques de niveau recherche, publiés ou non, émanant des établissements d'enseignement et de recherche français ou étrangers, des laboratoires publics ou privés.

\section{(c)(1)}

Distributed under a Creative Commons Attribution| 4.0 International License 


\section{Interlibrary loan and document supply in France -the Montpellier meeting}

The author: Joachim Schöpfel is Head of the Library and Document Supply Department of INIST-CNRS and lecturer at the University of Nancy, France.

Keywords: Document supply, interlibrary loan, France.

Abstract: The 21 October 2004, two professional associations (ADBU et AURA) invited for the first nationwide meeting on interlibrary loan and document supply in France. The paper provides a synthesis of some major communications and debate.

More than 100 managers of academic libraries and interlibrary loan (ILL) sections followed the invitation for the first nationwide meeting on French ILL network (PEB*, see glossary) and document supply. This meeting had been organized by ADBU* and AURA* and was held the 21 October 2004 at the University of Languedoc at Montpellier.

Perrin (University of Provence at Aix-en-Provence) and Kalfon (University of Paris-5) chaired two sessions with eleven communications that gave insight into various aspects of the development and changing role of the ILL network (first session) and, more technically, of cost analyses and financial transactions in the system (second session).

The goal of this first meeting was twofold: discuss the results of a joint working group on ILL and document supply and give some orientations for the future. The ABES*, as the operating agent of the French academic ILL system, offered a running buffet in honour of its $10^{\text {th }}$ birthday.

\section{First session: Evolving functions of libraries in the French network}

The meeting was opened by an updated version of Boukacem's study on the French ILL system since 1975 (see Boukacem 2003). Between 1995 and 2002, the ILL requests decreased from 700,000 to 400,000 transactions. Only $25 \%$ of these transactions were loans; the rest was document supply of print copies. The decrease is more important for science and technology sections than for medicine or social sciences and humanities. A small part of these requests are transactions from or to foreign countries $(<5 \%)$; nearly $20 \%$ requests are from nonacademic users. Based on empirical date gathered in more than 40 interviews, Boukacem identified as major factors of the decrease of traditional ILL the growing success of the French academic consortium COUPERIN* and the difficult financial situation of most of the academic libraries.

Kalfon held the second keynote of the morning. He described the members of the ILL network as follows: "all are users, most of them are loaners, but only some of them are suppliers". The decreasing number of requests leads to a new configuration characterized by greater diversity and distributed roles. Some major suppliers appear with important holdings, efficient organisation, good quality of service and complementary revenues. The keynote concluded with a plaidoyer for a fine analysis and a re-definition of this new configuration, built on each library's priorities, capacities, scientific specialities and so on. This would 
include a sort of "Charta of suppliers" which would give some orientations and guarantee a minimum service level.

Two other communications addressed the relationship between conservation and document supply (Sanz, former director of the CTLes*, see also Sanz 2003) and the cooperation between research (INIST*) and higher education (PEB) in document supply (Schöpfel). Rochard from the University of Grenoble proposed a list of criteria how to become a "good supplier". She asserted that while the overall number of requests decreases, the customers' exigencies increase - they want assistance and consulting, need a simple interface, ask for uncomplicated payment facilities, short delays, and good copy quality; and of course, low prices. Other conditions for a "good supplier" are situated in the library's "back-office": the richness of holdings and the legal right to supply, the structure's real motivation to be supplier (which implies resource allocation), a clear definition of goals in terms of efficiency and results, financial control and cost reduction, a simple price structure and a low price level, finally the use of evaluation tools.

The following debate was rich and controversial and covered several aspects, from the relationship between acquisition and supply policy, the role of the national catalogue SUDOC*, the impact of human resources downsizing on service quality, to the limits of resource rationalization, supply of electronic copies and the cooperation with the COUPERIN consortium. Cobolet from the BIUM* (Paris) claimed that the ILL system had become a sort of "marketplace" where users and suppliers define freely and openly the conditions of transaction - for Cobolet, the customer-user anyway goes where he finds what he wants for the best conditions, without caring for networks, structures, missions and so on.

\section{Second session: Financial aspects of the ILL system}

Boukacem introduced the second session with an overview on pricing policies and different approaches to cost/benefit analysis. Which charges should be considered: only direct servicerelated expenditures or also indirect charges for human resources and document acquisition? And what about revenues? All academic libraries reinvest supply revenues into collection acquisition and service quality. Is it then realistic and reasonable to speak of "benefits"? According to Boukacem's empirical data, pricing policies are hardly determined by financial analysis but habitually follow "a logic of compromise" between the library's self-defined "missions" and the needs and resources of its end-users.

"We have to introduce an element of liberalism into our activity" was the credo of Colinmaire's highly interesting communication on his experience at the dynamic University of Metz. In the context of the ongoing (liberal) reform of the French public administration, he carried out a detailed cost/benefit analysis with four major results: suppression of internal invoicing (no financial transactions between the library and other research and education structures on the Metz campus), reduction of external invoicing, out-sourcing of document supply (all requests are directly processed by INIST and delivered to the end-user), reorientation of acquisition policy to digital resources. For Colinmaire, the success of this choice after the first years is obvious: reduction of direct costs, increase of service quality, growing richness of collections and better valorisation of human resources.

Ménil of the Maine University at Le Mans described another experience of how to reduce costs and simplify procedures on a regional network level (Bretagne, Pays de Loire, Poitou- 
Charentes). Since 2003, the networked libraries tend to harmonise their pricing policies and reduce invoices by an annual invoicing with a sort of "balance" between the network members and suppression of invoices below a fixed level. It seems to work.

Finally, Bernon (University of Lyon-3) reported on an inquiry about the "financial behaviour" of university libraries and ILL sections, drawing an image of diversity and heterogeneity where a relevant part of document supply is organized outside of the academic network. Arguing from the results of his inquiry, Bernon underlined the importance of a functional and efficient interface between the libraries' management systems and the ILL network software, the SUPEB*.

\section{Concluding remarks}

Two communications concluded this first meeting on French ILL and document supply. The director of ABES that runs the academic union catalogue and the ILL network system, Sabine Barral, stressed with realism the limits of action - the necessity to act (and remain) in the legal context of French financial and administrative rules, and the need to harmonize pricing policies and financial choices between the different members of the network. Functionalities of the SUPEB software could and would develop (examples: improvement of the interface with local management systems, implementation of the international ILL standard) but this, too, requires a coherent analysis of objectives and behaviours.

In the name of the organization committee, Kalfon announced that the debate on the future of interlibrary loan and document supply in France will continue in partnership with both AURA and ADBU. The already existing working group will analyse experiences and options and try to obtain an at least minimal consensus for the evolution of the whole system.

To resume: With the increasing access to electronic resources, user needs for ILL and document supply are changing. In order to meet these needs, especially when confronted with budget cuts, academic libraries have to simplify procedures, optimise service and reduce costs. Communications and debate showed that this is not easy but possible. Paradoxically, the French universities' administrative and financial autonomy facilitates new experiences, concepts and models that could be transposed on a national level.

For more than one reason, the Montpellier conference was a historical meeting. Probably, others will follow. Some aspects that were a little bit "underexposed" during this first meeting will certainly gain more importance in the future, as for example the electronic delivery and related legal aspects (copyright, intellectual property), the international library service networking or the closer cooperation between some major French suppliers.

Presentations and papers will be accessible on the AURA website.

\section{Glossary}

ABES: Agence Bibliographique de l'Enseignement Supérieur (operating agent of the French academic catalogue and ILL system) http://www.abes.fr

ADBU: Association des Directeurs des Bibliothèques Universitaires (club of the heads of university libraries) http://www-sv.cict.fr/adbu/ 
AURA: Association du Réseau des Etablissements Utilisateurs de l'Agence Bibliographique de l'Enseignement Supérieur (user club of the ABES ILL system) http://aura.bu.univparis5.fr/

BIUM: Bibliothèque Interuniversitaire de Médecine (largest library of medicine in France and most important supplier in the academic sector) http://www.bium.univ-paris5.fr/

COUPERIN: French academic consortium for the acquisition of electronic resources. http://www.couperin.org/

CTLes: Centre Technique du Livre de 1'Enseignement Supérieur (deposit library of the Paris universities) http://www.ctles.fr/

INIST-CNRS: Institut de l'Information Scientifique et Technique du Centre National de la Recherche Scientifique (documentation centre of the most important French public research organisation) http://www.inist.fr

PEB: Prêt entre bibliothèque (French academic ILL network)

SUDOC: Système universitaire de documentation (academic union catalogue of serials and monographs) http://www.sudoc.abes.fr/

SUPEB: The academic ILL network software, developed by OCLC-PICA and run by ABES.

Web sites visited in November 2004.

\section{References}

Boukacem, C. (2003), "Inter-library loan services and the access to electronic resources in French university libraries: a marriage of reason", Interlending \& Document Supply, Vol. 31 No. 4, pp 218-227.

Sanz, P. (2003), "De la fourniture à distance de documents à la conservation partagée. L'engagement du CTLes", Bulletin des Bibliothèques de France, Vol. 48 No. 4, pp 33-37. 